\title{
Specify BRAF Exons Assessed
}

National Cancer Institute

\section{Source}

National Cancer Institute. Specify BRAF Exons Assessed. NCI Thesaurus. Code C160577.

A request to enter the BRAF exons assessed for mutations in this section of the form. 